\title{
Arbuscular mycorrhizal fungi as mitigating agents of salt stress in Formosa papaya seedlings
}

\author{
Francisco de Sales Oliveira Filho ${ }^{1 *}$, José Francismar de Medeiros ${ }^{\circledR}$, Marcelo Tavares Gurgel ${ }^{2}$, \\ Ewerton Gonçalves de Abrantes ${ }^{3}{ }^{(}$, Hermano Oliveira Rolim $^{1}{ }^{\circledR}$, Carlos Alberto Lins Cassimiro $^{\left({ }^{\circledR}\right.}$ \\ 'Federal Institute of Education, Science and Technology of Paraíba, Sousa, Brazil \\ ${ }^{2}$ Federal Rural University of the Semi-Arid, Mossoró, Brazil \\ ${ }^{3}$ Federal University of Paraíba, Areia, Brazil \\ ${ }^{4}$ National Semi-Arid Institute, Campina Grande, Brazil \\ ${ }^{*}$ Corresponding author, e-mail: salesoliveira6@hotmail.com
}

\begin{abstract}
The objective of the present study was to evaluate the effect of mycorrhization on the nutritional, hydric and biochemical components of papaya seedlings, Carica papaia L., from the Formosa Group, Hybrid Tainung $N^{\circ}$ 1, submitted to irrigation with saline water. The research was conducted at the Federal Institute of Paraíba, Sousa Campus, from March to December 2018. The experimental design used completely randomized blocks, with treatments arranged in a $4 \times 5$ factorial scheme, referring to the fungi species: Gigaspora candida, Acaulospora scrobiculata, Dentiscutata heterogama and without mycorrhizae, and the five salt concentrations in irrigation water: $0.0 ; 10.0 ; 20.0 ; 30.0$ and $40.0 \mathrm{mmol}_{\mathrm{c}} \mathrm{L}^{-1}$ in four repetitions. The characteristics evaluated were: relative water content, water saturation deficit, membrane damage, photosynthetic pigments, concentration and accumulation of nitrogen, phosphorus, potassium, sodium and the relationship between potassium and sodium concentrations in leaf tissue. The species $D$. heterogama and $G$. candida presented the highest rates of leaf hydration and the lowest damage to biomembranes at all saline levels. Mycorrhizae increased the absorption of $\mathrm{N}$ and $\mathrm{P}$, especially from $30 \mathrm{mmol}_{\mathrm{C}} \mathrm{L}^{-1}$ of salt. A greater relationship between potassium and sodium concentrations was evidenced in seedlings mycorrhized with $D$. heterogama.
\end{abstract}

Keywords: Carica papaia L., salinity, endomycorrhizae, AMFs

\section{Introduction}

Using saline water for irrigating seedlings of fruit species is a reality for fruit growers in semi-arid climate regions in Northeastern Brazil, as this is oftentimes the only available water source. However, salt is known to disturb plant metabolism, which may be related to biophysical factors such as the osmotic effect that restricts water transport and triggers a cascade of degenerative events that can lead to plant death (Hashem et al., 2018). In addition, the ionic effect can denature proteins and cause plasma membranes to become unstable (AbdAlla et al., 2019).

Regarding salinity, different tolerance levels have been suggested for papaya trees, depending on the cultivar, its stage of development, the cultivation environment and cultural management. For Sá et al. (2013), an electrical conductivity in water (ECW) greater than or equal to $2.0 \mathrm{dS} \mathrm{m}^{-1}$ ceases the growth and accumulation of biomass during the production phase of papaya seedlings. However, according to Coelho et al. (2008), electrical conductivity in saturation extract

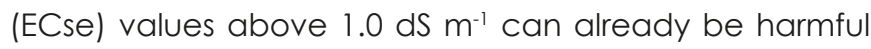
to papaya crops.

Plants colonized with arbuscular mycorrhizal fungi (AMFs) have been used alongside other commonly used techniques to manage the soil-water-plant system in areas affected by salinity (Wu et al., 2013; Zhang et al., 2018). Previous studies have proven the efficiency of mycorrhization in mitigating the adverse effects of water salinity on the nutritional, biochemical and physiological components of plants (Navarro et al., 2014). However, in general, the responses of mycorrhized plants depend on the species of plant and fungus introduced (Daei et al., 2009), as well as on the extent, duration and type of stress (Navarro et al., 2011).

When mycorrhizal plants are irrigated with 
saline water they more efficiently absorb mineral nutrient elements such as nitrogen $(N)$, phosphorus $(P)$, potassium (K) and micronutrients, reduce their absorption of potentially toxic ions such as sodium $\left(\mathrm{Na}^{+}\right)$and chloride $\left(\mathrm{Cl}^{-}\right.$) and regulate cellular ionic balance (Elhindl et al., 2017; Hashem et al., 2018). Additionally, nutritional improvement occurs since AMFS benefit physiological processes such as increased water absorption capacity by plants; a condition that increases the hydraulic conductivity of roots (Harris-Valle et al., 2018).

Within this context, the aim of this study was to evaluate the potential of mycorrhization in mitigating salt stress in the hydric, biochemical and nutritional components of papaya tree seedlings of the Formosa group, hybrid Tainung no. 1, cultivated in the Alto Sertão of Paraíba.

\section{Material and Methods}

The experiment was conducted in the seedling nursery of the Federal Institute of Education, Science and Technology of Paraíba, IFPB, Sousa Campus, São Gonçalo Unit, from March to December 2018. The experimental area is located at geographic coordinates $6^{\circ} 50^{\prime} 39.5^{\prime \prime} \mathrm{S}$, $38^{\circ} 17^{\prime} 40.10^{\prime \prime} \mathrm{W}$, with $234 \mathrm{~m}$ altitude.

A randomized block experimental design was used, with the sources of variation arranged in a $4 \times 5$ factorial scheme, where the four factor 1 levels corresponding to biological inputs of different arbuscular mycorrhizal species: Gigaspora candida, Acaulospora scrobiculata, Dentiscutata heterogama, and a control level without mycorrhizae. The five factor 2 levels corresponded to the dilution of different salt concentrations in irrigation water $10.0 ; 10.0 ; 20.0 ; 30.0$ and $40.0 \mathrm{mmol}_{\mathrm{c}} \mathrm{L}^{-1}$ ), in four replications, totaling 80 experimental units; which consisted of five $3 \mathrm{dm}^{3}$ pots with one papaya plant in each, totaling 400 plants.

The mycorrhizal fungi inoculums, composed of a mixture of soil, colonized roots, hyphae and about 75 mycorrhizal spores, were taken from the cultivation collection of Embrapa Agrobiology, Seropédica-RJ., three Tainung $N^{0} 1$ hybrid Formosa papaya seeds were planted $3 \mathrm{~cm}$ deep in a $3 \mathrm{dm}^{3}$ pot filled with the previously mentioned substrate, and were thinned when plants presented two definite leaves, maintaining only one plant per container.

The soil used in the experiment was collected at a depth of 0-20 cm, from an area located at IFPB, Sousa Campus. Before being applied to the substrate, it was sieved, mixed with washed sand in 1:1 ( $/ / \mathrm{v})$ proportion and sterilized in an autoclave twice at $121^{\circ} \mathrm{C}$ for one hour (Lima et al., 2011 ). After autoclaving the soil/sand mixture, physical and chemical analyses were performed at the IFPB Soil and Water Analysis Laboratory, Sousa Campus (Table1).

Table 1. Physical, chemical and fertility characteristics of the autoclaved 1:1 soil/sand mixture (v/v) used to produce Tainung $N^{0} 1$ Papaya seedlings

\begin{tabular}{|c|c|c|c|c|c|c|c|c|c|c|}
\hline \multicolumn{11}{|c|}{ Physical Characteristics } \\
\hline \multicolumn{3}{|c|}{ Granulometric Fraction } & \multirow{2}{*}{\multicolumn{2}{|c|}{$\begin{array}{c}\text { Soil } \\
\text { Density } \\
\mathrm{g} \mathrm{cm}^{3}\end{array}$}} & \multirow{2}{*}{$\begin{array}{l}\text { Real } \\
\text { Density } \\
\mathrm{g} \mathrm{cm}^{3}\end{array}$} & \multirow{2}{*}{$\begin{array}{l}\text { Total } \\
\text { Porosity } \\
\mathrm{m}^{3} \mathrm{~m}^{3}\end{array}$} & \multirow[b]{2}{*}{0.01} & \multirow{2}{*}{$\begin{array}{c}\text { Humidity } \\
\text { MPa } \\
0.033\end{array}$} & \multirow[b]{2}{*}{1.5} & \multirow[b]{2}{*}{$\begin{array}{c}\text { Texture } \\
\text { Class }\end{array}$} \\
\hline Sand & $\begin{array}{c}\text { Silt } \\
\text { g kg }\end{array}$ & Clay & & & & & & & & \\
\hline 908 & 42 & 50 & & 1.50 & 2.85 & 0.47 & 140 & 114 & 58 & Areia \\
\hline \multicolumn{11}{|c|}{ Chemical \& Fertility Characteristics } \\
\hline $\mathrm{pH}$ & $\mathrm{P}$ & $\mathrm{K}^{+}$ & $\mathrm{Na}^{+}$ & $\mathrm{Ca}^{+2}$ & $\mathrm{Mg}^{+2}$ & $\mathrm{Al}^{+3}$ & $\mathrm{H}^{+}+\mathrm{Al}^{+3}$ & BS & CEC & OM PES \\
\hline $\mathrm{H}_{2} \mathrm{O}$ & $\mathrm{mg} \mathrm{L}^{-3}$ & \multicolumn{8}{|c|}{---------------------------------------- $\mathrm{Cmol}_{\mathrm{c}} \mathrm{L}^{-3}------------------------$} & ------\%---- \\
\hline 8.2 & 134 & 0.21 & 0.37 & 5.8 & 0.3 & 0.00 & 0.00 & 6.68 & 6.68 & $0.37 \quad 6$ \\
\hline
\end{tabular}

The potassium was added to the substrate until a level of $100 \mathrm{mg} \mathrm{dm}^{-3}$, was reached (Lima et al., 2011), and N, S and micronutrients in coverage were added via nutritive solution, totaling $1.8 \mathrm{~g} \mathrm{dm}^{-3}$ of $\mathrm{N}$ (Mendonça et al., 2006), $36.8 \mathrm{mg} \mathrm{dm}^{-3}$ of $S$, divided into five applications and $0.81 \mathrm{mg} \mathrm{dm}^{-3}$ of $\mathrm{B}, 3.6 \mathrm{mg} \mathrm{dm}^{-3}$ of $\mathrm{Mn}, 1.3 \mathrm{mg} \mathrm{dm}^{-3}$ of $\mathrm{Cu}, 3.9 \mathrm{mg} \mathrm{dm}^{-3}$ of $\mathrm{Zn}, 0.15 \mathrm{mg} \mathrm{dm}^{-3}$ of $\mathrm{Mo}$, and $1.6 \mathrm{mg}$ $\mathrm{dm}^{-3}$ of Fe were applied once after thinning (Trindade ef al., 2001).

The irrigation waters with different salinity levels were prepared by adding sodium chloride salts $(\mathrm{NaCl})$, Calcium chloride $\left(\mathrm{CaCl}_{2} 2\left(\mathrm{H}_{2} \mathrm{O}\right)\right)$ and magnesium chloride $\left(\mathrm{MgCl}_{2} 6\left(\mathrm{H}_{2} \mathrm{O}\right)\right)$, in the proportion of 7:2:1, respectively, to water with known salt concentration, at levels of 0.0; 10.0; 20.0; 30.0 and $40.0 \mathrm{mmol}_{\mathrm{C}} \mathrm{L}^{-1}$. The first level was considered the control, as CE did not change. The salts proportion used followed Audry \& Suassuna (1995), as it presented the average water composition for northeastern Brazil. The stock solutions with the different salt levels were stored separately in 220-liter drums.

Samples of the waters with different salinity levels were collected for physiochemical characterization (Table 2). Plants were irrigated daily, leaving soil moisture close to the maximum retention capacity, based on the weighing method, and applied depth was increased by a leaching fraction of $20 \%$. 
Table 2. Physiochemical water characteristics, including the 5 salinity levels used to irrigate the Tainung $N^{\circ} 1$ Formosa Papaya seedlings.

\begin{tabular}{|c|c|c|c|c|c|c|c|c|c|c|}
\hline \multicolumn{11}{|c|}{ Physiochemical water characteristics } \\
\hline CE & $\mathrm{pH}$ & $\mathrm{K}^{+}$ & $\mathrm{Na}^{+}$ & $\mathrm{Ca}^{+2}$ & $\mathrm{Mg}^{+2}$ & $\mathrm{SO}_{4}^{-2}$ & $\mathrm{Cl}^{-}$ & $\mathrm{CO}_{3}^{-2}$ & $\mathrm{HCO}_{3}^{-}$ & RAS \\
\hline $\mathrm{dS} \mathrm{m}^{-1}$ & & ------ & - & ----- & $\mathrm{mol}_{\mathrm{c}} \mathrm{a}$ & 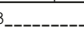 & 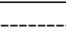 & ---- & & $\mathrm{mmol}_{\mathrm{c}} \mathrm{dm}^{-3}$ \\
\hline 0.01 & 7.4 & 0.01 & 0.03 & 0.1 & 0.3 & 0.047 & 1.1 & 0.00 & 0.52 & 0.07 \\
\hline 1.3 & 6.4 & 0.03 & 7.21 & 2.4 & 0.9 & 0.047 & 13.0 & 0.00 & 0.50 & 5.62 \\
\hline 2.3 & 6.5 & 0.03 & 15.50 & 4.5 & 2.2 & 0.000 & 21.4 & 0.00 & 0.62 & 8.47 \\
\hline 3.3 & 6.3 & 0.03 & 23.00 & 6.5 & 3.1 & 0.034 & 31.8 & 0.00 & 0.54 & 10.5 \\
\hline 4.3 & 6.4 & 0.05 & 31.93 & 8.6 & 4.3 & 0.052 & 46.0 & 0.00 & 0.60 & 12.57 \\
\hline
\end{tabular}

The hydric status of papaya tree plants was evaluated by determining the relative water content (RWC) and water saturation deficit (WSD) in leaf discs (Catsky, 1974). The chlorophyll and carotenoid contents were also evaluated using the methods of Lichthenthaler (1987), expressed in $\mathrm{g} \mathrm{kg}^{1}$ of fresh mass $\left(\mathrm{g} \mathrm{kg}^{-1}\right)$. The integrity of the plasma membranes of leaf tissue cells was determined by electrolyte extravasation following the method of Shanahan et al. (1990).

The concentration and accumulation of nutrients in leaf tissues were analyzed at 65 days after emergence (DAE). For this, the leaves were collected between 9 and $10 \mathrm{am}$, and immediately separated into limbus and petiole for drying in forced air circulation oven at $70^{\circ} \mathrm{C}$ for 48 hours. Afterwards, they were crushed in a mill (Wiley type) with a 20-mesh sieve. N, P and K were analyzed according to Tedesco (1995), $\mathrm{Na}+$ according to the method proposed by Chaudhary et al. (1996) and
$\mathrm{Cl}$ - according to the volumetric method of Mohr (Bezerra Neto \& Barreto, 2011).

The data was submitted to analysis of variance using the F test at a $5 \%$ t level. A Pearson's linear correlation analysis $(r)$ was also performed, with significance of correlations evaluated by the t-test at $5 \%$ probability. For the qualitative factor (mycorrhizae), the means of the variables were compared by the Tukey test at $5 \%$ and for the quantitative factor (salinity), polynomial regression models were adjusted. The statistical program SISVAR version 5.7 was used for these calculations (Ferreira, 2014).

\section{Results and Discussion}

There was a significant interaction between the factors: salinity of irrigation water and AMF species at different probability levels, where the interaction was significant at 0.05 for RWC and at a level of 0.01 for the other variables. Isolated effects $(p<0.01)$ of the study factors were also observed for all variables (Table 3).

Table 3. Summary of the analysis of variance for relative water content (RWC), water saturation deficit (WSD), membrane damage (MD), Chlorophyll a (Clh a), chlorophyll $a+b(C l h a+b)$ and carotenoids (Carot.) in Tainung $N^{\circ} 1$ Formosa Papaya seedlings, related to mycorrhization and irrigation water with different salt levels.

\begin{tabular}{lllllll}
\hline \multirow{2}{*}{ Sources of Variation } & \multicolumn{5}{c}{ Average squares } \\
\cline { 2 - 7 } & RWC & WSD & MD & Clh a & Clh a+b & Carot. \\
\hline Salinity (S) & $291.11^{* * *}$ & $291.11^{* *}$ & $945.79^{* *}$ & $0.59^{* *}$ & $0.34^{* *}$ & $0.00879^{* *}$ \\
Micorrhizae (M) & $1398.69^{* *}$ & $1398.69^{* *}$ & $2954.42^{* *}$ & $1.18^{* *}$ & $1.30^{* *}$ & $0.05779^{* *}$ \\
S X M & $53.39^{*}$ & $53.39^{* *}$ & $294.98^{* *}$ & $0.09^{* *}$ & $1.16^{* *}$ & $0.01472^{* *}$ \\
Block & $0.99^{\text {ns }}$ & $0.99^{\text {ns }}$ & $17.12^{\text {ns }}$ & $0.00^{\text {ns }}$ & $1.04^{*}$ & $0.000197^{\text {ns }}$ \\
Residual & 3.34 & 3.35 & 7.24 & 0.005 & 0.02 & 0.00206 \\
\hline CV (\%) & 2.35 & 8.27 & 7.85 & 10.29 & 19.27 & 17.78 \\
\hline
\end{tabular}

Source: Data obtained in this study; ns - non-significant influence; ${ }^{*} \mathrm{P}<0.05 ;{ }^{* *} \mathrm{P}<0.01$; CV - Variation Coefficient.

Inoculation with D. heterogama (DH) provided higher leaf tissue hydration and consequently lower water saturation deficit, when compared to the absence of AMF at all salinity levels, only presenting statistical differences ( $p>0.05$ ) when the $10 \mathrm{mmol}_{\mathrm{c}} \mathrm{L}^{-1}$ salt concentration was applied (Figure $1 \mathrm{~A} 1$ and $\mathrm{B} 1$ ). For the salt concentrations of 20,30 and $40 \mathrm{mmol}_{\mathrm{C}} \mathrm{L}^{-1}$, the AMF species DH and Gigaspora candida (GC) were responsible for the highest RWC and lowest WSD values, respectively, not differing statistically ( $p>0.05$ ). A $17.14 \%$ increase in RWC was provided by the DH species, when compared no mycorrhizae at the salt concentration of $40 \mathrm{mmol}_{\mathrm{C}} \mathrm{L}^{-1}$.
There was a linear trend towards reduced RWC and increased WSD with increased salinity. The water status of papaya seedlings was most threatened at 65 DAE due to the absence of AMF (WM), presenting $0.7 \%$ water loss for each $\mathrm{mmol}_{\mathrm{c}}$ of salts added to each liter of water (Figure 1 A2 and B2). The DH species was responsible for the highest mean RWC up to the salt concentration of $24.76 \mathrm{mmol}_{\mathrm{C}} \mathrm{L}^{-1}$. After this point, the GC species became the most tolerant with an RWC of $78.55 \%$.

Corroborating with the results found, Garg \& Singla (2012) also observed a higher RWC in mycorrhized Pisum sativum L. plants subjected to salt stress compared 
to non-mycorrhized plants. Furthermore, Harris-Valle et al. (2018) studied Cucurbita pepo plants mycorrhized with native and exotic species and non-mycorrhized plants subjected to drought and salt levels in the soil and found that native mycorrhizal fungi were more tolerant to water and salt stress. Similarly, Hashem et al. (2018) observed a

drastic decrease in RWC (50.03\%) for Cucumis sativus L. plants that were not mycorrhized and subjected to salt stress. These authors also found that using mycorrhizal fungi relieved the negative effect of salinity on the hydration of plant tissues.
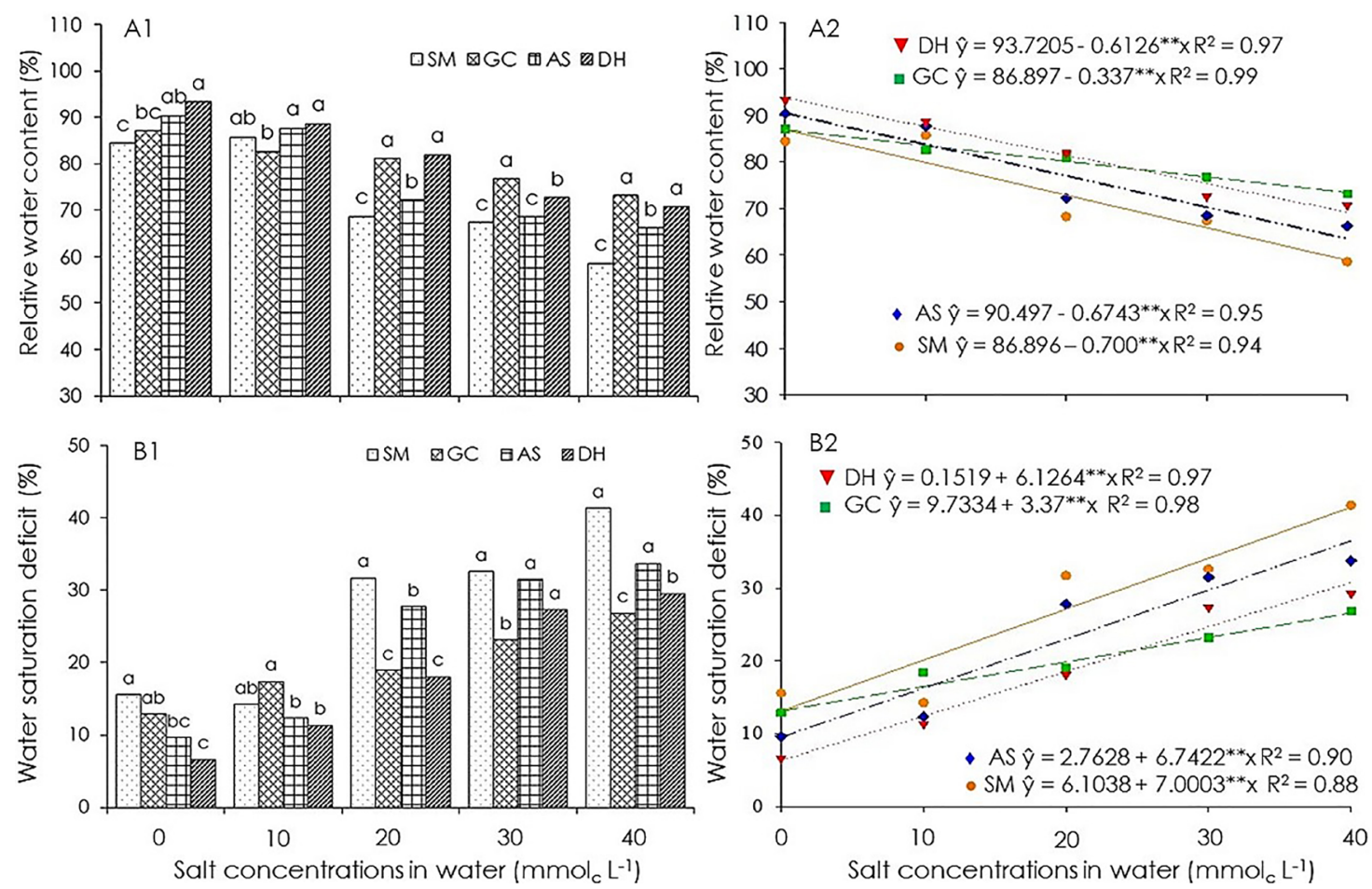

Figure 1. Relative water content (A) and water saturation deficit (B) in Papaya seedlings at 65 DAE, related to the mycorrhizae species within the salt concentrations (A1 \& B1) and the salt concentrations within each mycorrhizae species (A2 \& B2). (WM) without mychorhize (GC) Gigaspora cândida, (AS) Acaulospora scrobiculata and (DH) Dentiscutata heterogama. Note: Averages followed by the same letter do not differ by Tukey's test, with a $5 \%$ probability (Al \& B1).

The reduction of total water potential in the soil, due to increased salt concentration in its saturation extract, limits water availability for plants, with harmful and often irreversible consequences for the growth of most cultivated plants. Research reveals that the highest relative water content in mycorrhized plants can be credited to the highest volume of substrate explored by fungal hyphae (Miransari, 2017). The larger contact surface of extra-radicular hyphae when compared to root hairs leads to more efficient osmotic adjustment in plants colonized by AMFs (Hashem et al., 2018) and greater growth of root hair in host plants (Wu et al., 2010). Also, according to Gholamhoseini et al. (2013), mycorrhizal symbiosis can protect plants from the deleterious effects of water stress, due to the activation of plant defense mechanisms.

The cell membranes of Papaya seedlings inoculated with different AMF species were less damaged compared to non-mycorrhized seedlings at different salinity levels, except for those mycorrhized with
Acaulospora scrobiculata (AS), which presented more severe damage (Figure $2 \mathrm{~A} 1$ and $\mathrm{A} 2$ ) and did not differ statistically (Tukey test $(p>0.01))$ from the WM treatment at the salt levels of $10,20,30$ and $40 \mathrm{mmol}_{\mathrm{c}} \mathrm{L}^{-1}$.

The GC species lead to 24.9 and $31.89 \%$ damage at the salt levels of 30 and $40 \mathrm{mmol}_{c} \mathrm{~L}^{-1}$, respectively, which were statistically lower $(p<0.01)$ than those achieved by the WM treatment (45.23 and $60.6 \%$, respectively). The $\mathrm{DH}$ species provided the lowest damage and remained below the WM and AS Treatments, especially at the salt level of $40 \mathrm{mmol}_{\mathrm{C}} \mathrm{L}^{-1}$ (Figure 2A1).

An increasing linear trend was observed for the membrane damage curve as a function of increased salt concentrations, regardless of inoculation of papaya seedlings with different AMF species (Figure 2A2). However, using $D H$ and $G C$ species minimized these damages, presenting the lowest percent of damage in absolute terms, when compared to the AS and WM treatments. 

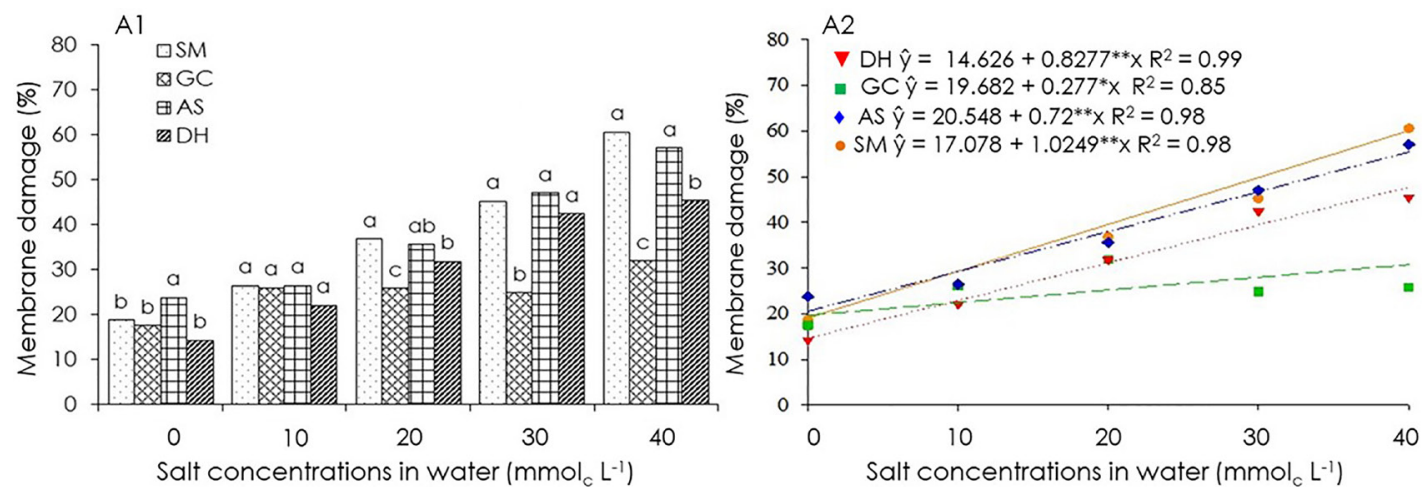

Figure 2. Membrane damage in leaf tissue cells (A) of papaya seedlings at $65 \mathrm{DAE}$, depending on the mycorrhizae species within the salt concentrations (A1) and the salt concentrations within each of the mycorrhizae species (A2). (WM) without mycorrhizae, (GC) Gigaspora candida, (AS) Acaulospora scrobiculata and (DH) Dentiscutata heterogama. Note: Averages followed by the same letter do not differ by Tukey's test, at a $5 \%$ probability level (A1).

Cell membrane damages are commonly observed in plants exposed to abiotic stresses, especially saline stress (Hashem et al., 2019). There are numerous studies that prove the deleterious effects of salinity on the stability of plasma membranes, which is relieved by mycorrhizae colonization (Navarro et al., 2014; Amanifar et al., 2019) depending on the AMF species used, corroborating the results observed in the present study.

The increased concentration of reactive oxygen species (ROS) in the cellular protoplasm causes lipid peroxidation of membranes, which is favored by salinity (Hashem et al., 2018). However, this damage is relieved by the synthesis of antioxidant compounds, such as proline and glycine-betaine, as well as increased activity of superoxide dismutase (SOD), catalase (CAT), and ascorbate peroxidase (APX), since their synthesis and activities are intensified in mycorrhized plants.

At all salinity levels, the DH species was responsible for the highest chlorophyll a concentration (Clh a), except at the highest salinity level $\left(40 \mathrm{mmol}_{\mathrm{c}} \mathrm{L}^{-1}\right)$, which presented no significant difference from the CG and WM (p>0.05) treatments (Figure 3A1). The concentrations of chlorophylls $a+b(C l h a+b)$ were higher when related to $\mathrm{DH}$ inoculation at all salinity levels, differing $(\mathrm{p}<0.05)$ from AS and GC, at the salinity level of $30 \mathrm{mmol}_{\mathrm{C}} \mathrm{L}^{-1}$, and $\mathrm{WM}$ at 0 and $10 \mathrm{mmol}_{\mathrm{C}} \mathrm{L}^{-1}$ (Figure 3B 1).

Regarding the concentrations of carotenoids (Carot.), at salt concentrations 0,10 and $20 \mathrm{mmol}_{\mathrm{c}}$ $\mathrm{L}^{-1}$, the use of different AMF species favored higher concentrations when compared to WM. However, at salt concentrations of 30 and $40 \mathrm{mmol}_{\mathrm{c}} \mathrm{L}^{-1}$ the leaves of non-mycorrhized papaya plants presented a higher concentration of this pigment (Figure $3 \mathrm{Cl}$ ).

Decreasing linear trends of the concentrations of chlorophyll $a, a+b$ and Carot. $(p<0.01)$ were found in relation to elevated salinity for the different $A M F$ species. However, for the WM treatment, the lowest levels of photosynthetic pigments and a differentiated behavior in their concentration were observed regarding elevated salinity, presenting a decreasing linear trend for $\mathrm{Chl} a$, a quadratic behavior for $\mathrm{Chl} a+b$, with a higher concentration of $0.699 \mathrm{~g} \mathrm{~kg}^{-1}$ of fresh mass (FM) observed at $2.49 \mathrm{mmol}_{\mathrm{C}} \mathrm{L}^{-1}$ of salt, and an increasing linear trend for carotenoid concentrations (Figure 3A2, B2 and C2).

According to Hashem et al. (2018), mycorrhizae can regulate enzyme activity involved in chlorophyll synthesis concomitantly with decreased chlorophyll activities in plants subject to saline environments, favoring increased concentrations of these pigments in leaves.

Another consequence of the depressive effect of salinity on pigment synthesis is the antagonistic effect of $\mathrm{Na}^{+}$on $\mathrm{Mg}^{2+}$ absorption, which is one of the components of chlorophyll molecules (Navarro et al., 2014). These same authors observed that using mycorrhizae in citrus rootstocks decreased the absorption of $\mathrm{Na}^{+}$and increased that of $\mathrm{Mg}^{2+}$, which favored higher total chlorophyll concentrations.

The degree of relationship between RWC, MD and photosynthetic pigments, as a function of the interaction between the different mycorrhizae and water salt concentrations was evaluated by Pearson's linear correlation test ( $r$ ) (Table 4), which presented different levels of significance when evaluated by the t test at $5 \%$ probability.

A strongly negative correlation $(p<0.05)$ was observed between RWC and variables WSD ( $r=-1.00)$ and MD ( $r=-0.84)$, and a strongly positive one was observed with Clh a ( $r=0.78)$, Clh $a+b(0.75)$ and Carot. $(r=0.70)$. The negative correlation with MD and positive correlation with photosynthetic pigments demonstrates how important the hydric status of plants is for the stability of cellular structures and the maintenance of structures 
responsible for the photosynthetic processes, as well as how well AMFs provide these conditions. Hashem et al. (2018) also observed a strongly negative linear correlation $(p<0.01)$ between RWC and MD in mycorrhized Cucumis sativus L. plants submitted to salt stress, corroborating the results observed in the present study.

The intensity of the correlation was determined according to Figueiredo Filho \& Silva Júnior (2009) as weak $(0.1 \geq$ and $\leq 0.3)$, moderate $(0.4 \geq$ and $\leq 0.6)$ and strong $(0.7 \geq$ and $\leq 1.0)$.
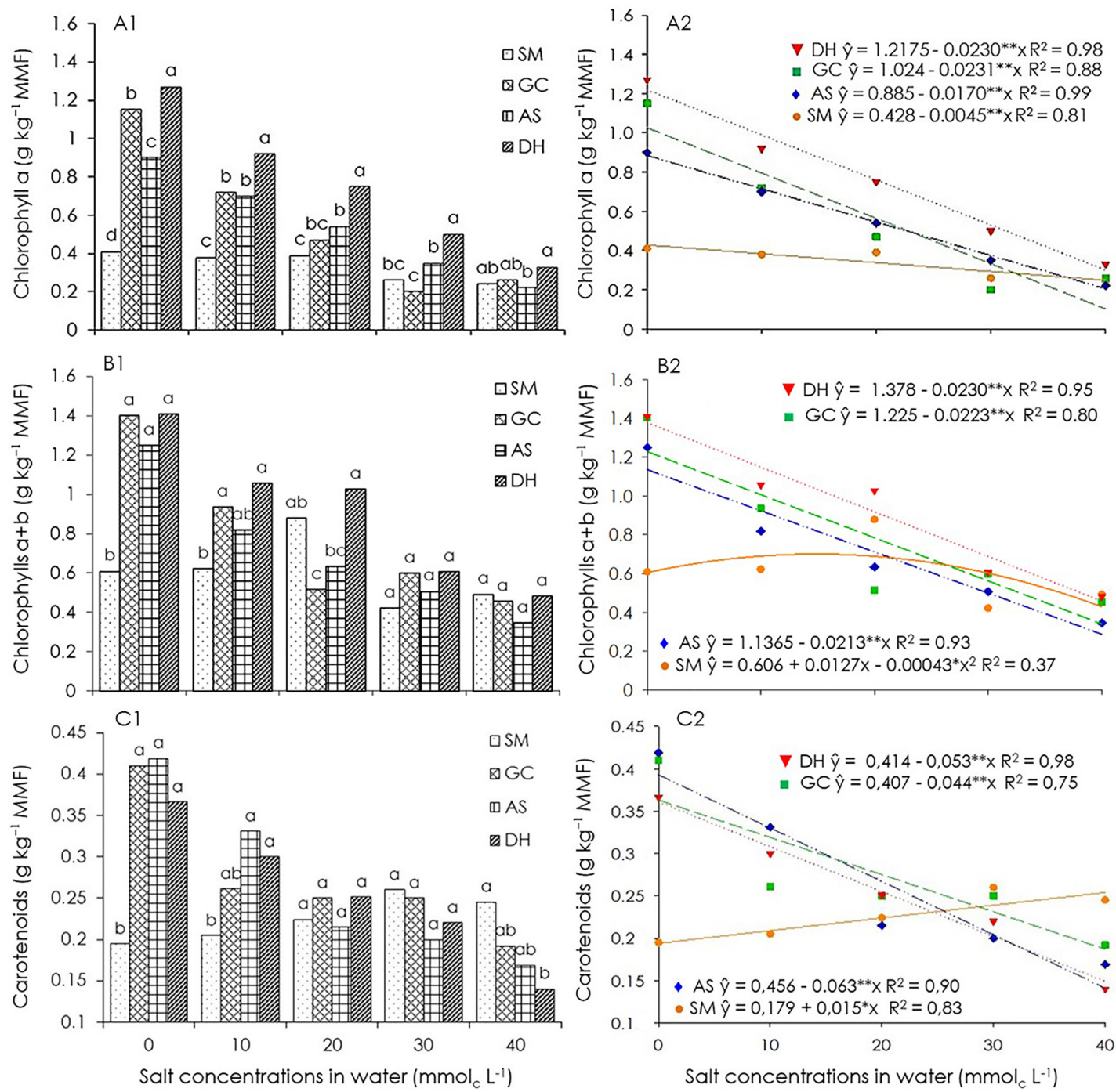

Figure 3. Concentrations of chlorophyll a (A), chlorophylls $a+b(B)$ and carotenoids (C) in leaves of papaya seedlings at $65 \mathrm{DAE}$, depending on the mycorrhizae species within the salt concentrations $(\mathrm{A} 1, \mathrm{~B} 1$ \& $\mathrm{C} 1)$ and salt concentrations within each of the mycorrhizae species (A2, B2 e C2). (WM) without mycorrhizae, (GC) Gigaspora candida, (AS) Acaulospora scrobiculata and (DH) Dentiscutata heterogama. Note: Averages followed by the same letter do not differ by Tukey's test, at a 5\% probability level (A1, B 1 \& C1).

Table 4. Pearson's linear correlation coefficient ( $r$ ), relative water content (RWC), water saturation deficit (WSD), membrane damage (MD), chlorophyll a (Clh a), chlorophyll $a+b(C l h a+b)$ and carotenoids (Carot.) from Tainung $\mathrm{N}^{\circ} 1$ Formosa papaya seedlings as a function of mycorrhizae and water irrigation with different salt levels.

\begin{tabular}{|c|c|c|c|c|c|c|}
\hline & RWC & WSD & $M D$ & Clh a & Clh $a+b$ & Carot, \\
\hline RWC & 1 & $-1.00^{* *}$ & $-0.84^{* *}$ & $0.78^{* *}$ & $0.75^{* *}$ & $0.70^{* *}$ \\
\hline WSD & & 1 & $0.84^{* *}$ & $-0.78^{* *}$ & $-0.74^{* *}$ & $-0.66^{* *}$ \\
\hline$M D$ & & & 1 & $-0.63^{* *}$ & $-0.67^{* *}$ & $-0.58^{* *}$ \\
\hline Clh a & & & & 1 & $0.94^{* *}$ & $0.81^{* *}$ \\
\hline Clh $a+b$ & & & & & 1 & $0.84^{* *}$ \\
\hline Carot & & & & & & 1 \\
\hline
\end{tabular}


Regarding nutrient concentrations and accumulations, a significant interaction between salinity of irrigation water and AMF species at different probability levels $(p<0.05$ and $p<0.01)$ is evidenced; where, the interaction was significant at 0.05 for $P$ concentration and at 0.01 for the other nutrient elements. Isolated effect $(p<0.01)$ of the study factors were also observed for all variables (Table 5).
Increased water salt concentration reduced the concentration and accumulation of nitrogen ( $N$ ) differently in the leaf tissue of mycorrhized papaya seedlings depending on the AMF species used, with the lowest levels observed in $S M$, especially at concentrations 20,30 and $40 \mathrm{mmol}_{\mathrm{C}} \mathrm{L}^{-1}$, when compared to mycorrhization with DH and GC species (Figure 4A1).

Table 5. Summary of the analysis of variance for concentration and accumulation of total Nitrogen (N), Phosphorus (P), Potassium $\left(\mathrm{K}^{+}\right)$, Sodium $\left(\mathrm{Na}^{+}\right)$and relationship between Potassium and Sodium $\left(\mathrm{K}^{+} / \mathrm{Na}^{+}\right)$ in the leaf tissue of Tainung $\mathrm{N}^{\circ} 1$ Formosa papaya seedlings due to mycorrhizae and water irrigation at different salt levels.

\begin{tabular}{|c|c|c|c|c|c|}
\hline \multirow{2}{*}{$\begin{array}{l}\text { Sources of } \\
\text { variation }\end{array}$} & \multicolumn{5}{|c|}{ Average squares for nutrient concentration ( $\mathrm{g} \mathrm{kg}^{\mathrm{l}}$ ) } \\
\hline & $\mathrm{N}$ total & $\mathrm{P}$ & $\mathrm{K}^{+}$ & $\mathrm{Na}^{+}$ & $\mathrm{K}^{+} / \mathrm{Na}^{+}$ \\
\hline Salinity (S) & $60.9928^{* *}$ & $12.585^{* *}$ & $27.3356^{* *}$ & $25.7486^{* *}$ & $2,291^{* *}$ \\
\hline Mycorrhizae (M) & $8.6503^{* *}$ & $4.393^{* *}$ & $28.7309^{* *}$ & $354.626^{* *}$ & $149,148^{* *}$ \\
\hline$S \times M$ & $77.5194^{* *}$ & $3.755^{*}$ & $12.5464^{* *}$ & $24.373^{* *}$ & $2,418^{* *}$ \\
\hline Block & $0.705^{\text {ns }}$ & $0.55^{\mathrm{ns}}$ & $0.164^{\mathrm{ns}}$ & $0.826^{\text {ns }}$ & $0,0524^{\mathrm{ns}}$ \\
\hline Residual & 3.65 & 0.175 & 0.45 & 0.734 & 0,217 \\
\hline CV (\%) & 5.93 & 9.55 & 7.71 & 13.13 & 16,12 \\
\hline \multirow{2}{*}{$\begin{array}{c}\text { Sources of } \\
\text { variation }\end{array}$} & \multicolumn{5}{|c|}{ Average squares for nutrient accumulation (mg plant ${ }^{-1}$ ) } \\
\hline & $\mathrm{N}$ total & $\mathrm{P}$ & $\mathrm{K}^{+}$ & & $\mathrm{Na}^{+}$ \\
\hline Salinity (S) & $807.9964^{* *}$ & $22.6673^{* *}$ & 119.69 & & $48.3642^{* *}$ \\
\hline Mycorrhizae (M) & $689.0185^{* *}$ & $12.1317^{* *}$ & 181.18 & & $22.4318^{* *}$ \\
\hline$S \times M$ & $124.6364^{* *}$ & $1.3209^{* *}$ & 9.530 & & $7.0766^{* *}$ \\
\hline Block & $3.8816^{\text {ns }}$ & $0.4978^{\text {ns }}$ & 0.477 & & $0.8592^{\mathrm{ns}}$ \\
\hline Residual & 4.7020 & 0.152 & 0.64 & & 0.4385 \\
\hline $\mathrm{CV}(\%)$ & 10.35 & 12.33 & 11.8 & & 17.51 \\
\hline
\end{tabular}
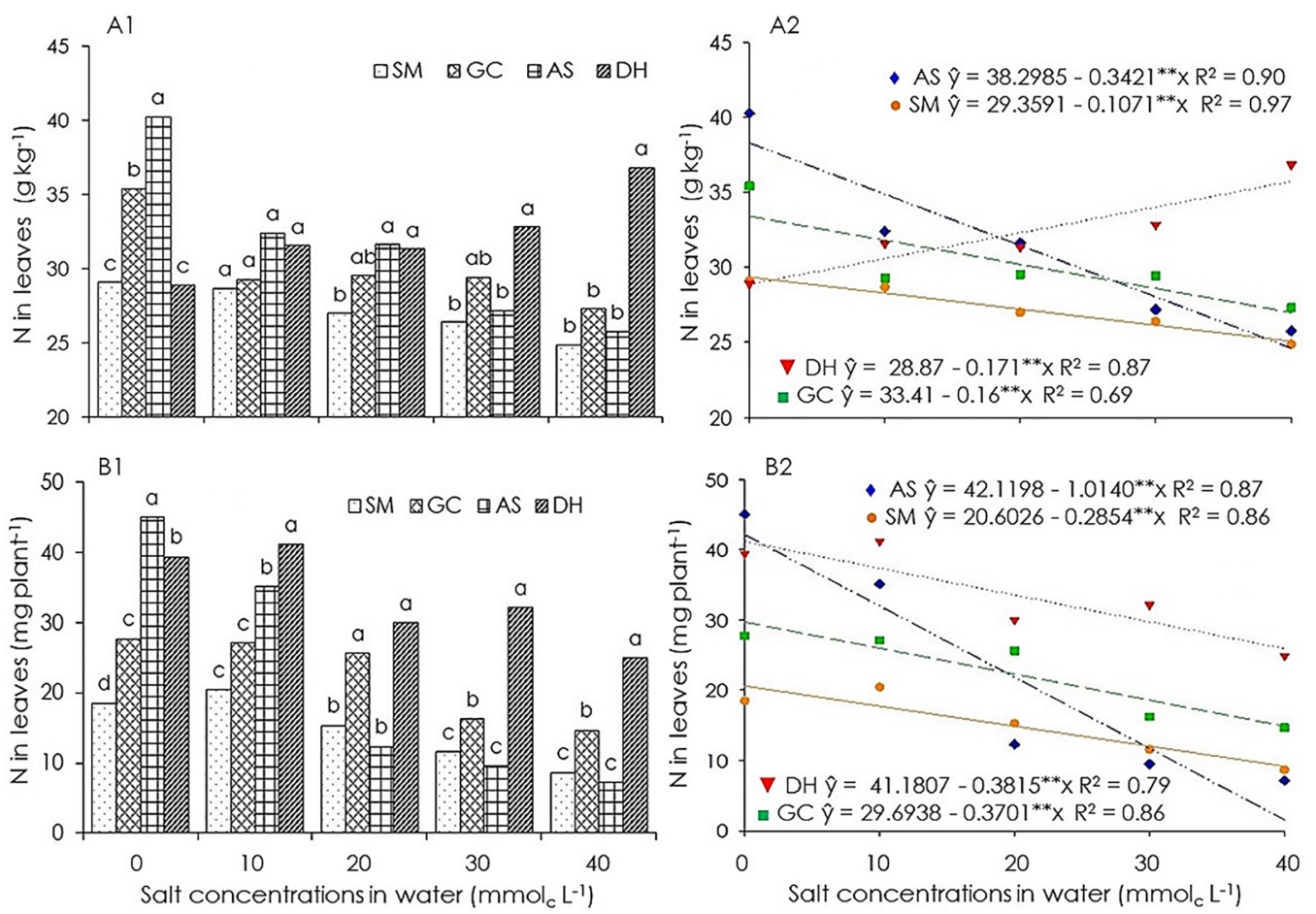

Figure 4. Concentration (A) and accumulation (B) of total nitrogen $(N)$ in leaves of papaya seedlings, $65 \mathrm{DAE}$, depending on the mycorrhizae species within the salt concentrations (A1 \& B1) and the salt concentrations within each of the mycorrhizae species (A2 \& B2). (WM) without mycorrhizae, (GC) Gigaspora candida, (AS) Acaulospora scrobiculata and (DH) Dentiscutata heterogama. Note: Means followed by the same letter do not differ by Tukey's test at a 5\% probability level (A1 \& B1). 
$\mathrm{N}$ levels in plants mycorrhized with $\mathrm{DH}$ increased linearly with increased salt concentrations, ranging from 28.9 to $36.84 \mathrm{~g} \mathrm{~kg}^{-1}$ as a function of 0 and $40 \mathrm{mmol}_{\mathrm{c}} \mathrm{L}^{-1}$ of salts, representing a $0.17 \mathrm{~g} \mathrm{~kg}^{-1}$ increase of $\mathrm{N}$ per mmol of salt added to each liter of water (Figure 4A2). The highest $\mathrm{N}$ accumulations were, also observed in seedling mycorrhized with $\mathrm{DH}$, mainly in waters with salts $(10,20,30$ and $\left.40 \mathrm{mmol}_{\mathrm{c}} \mathrm{L}^{-1}\right)$, presenting higher values than seedlings without mycorrhizae and those inoculated with GC and AS species at all saline levels.

When correlating the accumulation of nutrients provided by the different AMF species to increased salinity ( 0 to $\left.40 \mathrm{mmol}_{\mathrm{c}} \mathrm{L}^{-1}\right)$, there was a reduction of around 47.12; 76.66 and $36.89 \%$ for GC, AS and DH, respectively. Thus, the DH species showed the highest tolerance to the negative effect of salinity for the absorption of this nutrient (Figure 4B1).

As seen herein, Gholamhoseini et al. (2013) also observed improvements in $\mathrm{N}$ concentration in leaves of mycorrhized sunflower plants submitted to water stress, finding 17 and $6 \%$ increases of this nutrient in plants mycorrhized with the species Glomus mosseae and Glomus hoi. According to these authors, such increases are related to higher water absorption efficiency, as well as the expansion of the area explored by fungal hyphae associated with root hairs.

One of the mechanisms related to improved nitrogen absorption provided by AMF is related to their ability to convert organic $\mathrm{N}$ from the soil into mineral $\mathrm{N}$, since mycorrhizal fungi excrete proteases that break down organic matter and subsequently capture nitrogen-containing compounds, thus providing a direct link between the organically complexed nitrogen in the soil and the plant (Schimel \& Bennett 2004).

Higher phosphorus (P) concentrations were found in non-mycorrhized plants (WM) when exposed to the lowest salinity levels 0,10 and $20 \mathrm{mmol}_{\mathrm{C}} \mathrm{L}^{-1}$, compared to inoculation with the GC, AS and DH species. However, under severe salinity conditions, the highest $P$ concentrations were correlated to mycorrhization with AS at $30 \mathrm{mmol}_{\mathrm{C}} \mathrm{L}^{-1}$ and DH at $40 \mathrm{mmol}_{\mathrm{C}} \mathrm{L}^{-1}$ (Figure $5 \mathrm{~A} 1$ ).
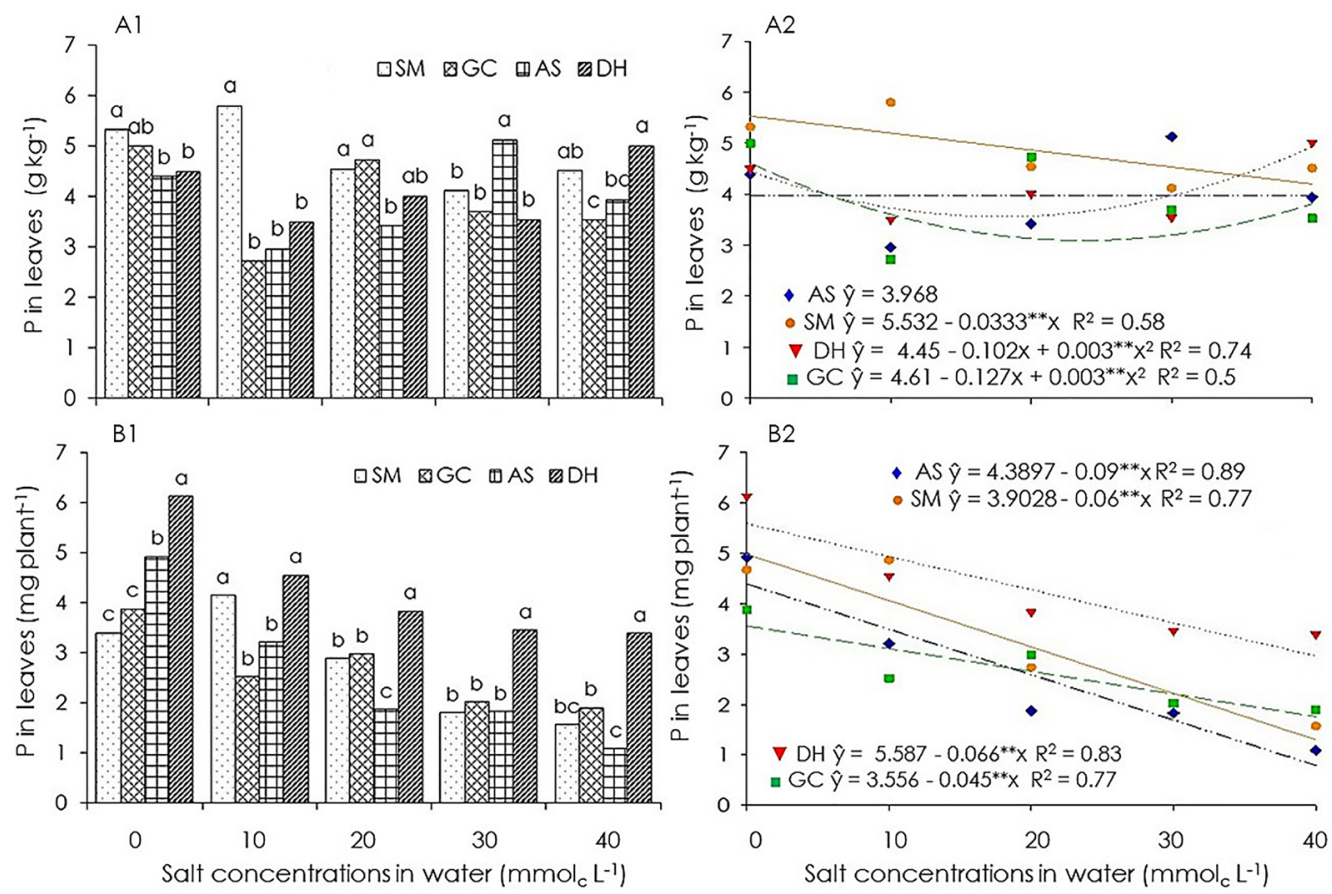

Figure 5. Concentration (A) and accumulation (B) of phosphorus (P) in leaves of papaya seedlings, $65 \mathrm{DAE}$, related to the mycorrhizae species within the salt concentrations (Al e B1) and the salt concentrations within each one of the mycorrhizae species (A2 \& B2). (WM) without mycorrhizae, (GC) Gigaspora candida, (AS) Acaulospora scrobiculata and (DH) Dentiscutata heterogama. Note: Means followed by the same] letter do not differ by Tukey's 'test at a 5\% probability level (A) \& B1).

A decreasing trend in $P$ concentration was observed correlated to inoculation with $\mathrm{GC}$ and $\mathrm{DH}$ species up to salt concentrations 23.52 and $16.6 \mathrm{mmol}$ $\mathrm{L}^{-1}$, with $\mathrm{P}$ averages of 3.09 and $3.61 \mathrm{~g} \mathrm{~kg}^{-1}$, respectively, tending to increase by up to 14.24 and $38.78 \%$ from these points (Figure 5A2).

For $\mathrm{P}$ accumulation, a decreasing linear trend was correlated to increased salinity, with variable losses for the different mycorrhizae treatments; where the lowest $\mathrm{P}$ accumulation was observed in non-mycorrhized 
plants, as well as for inoculation with AS and CG. The AS treatment presented the greatest relative losses, which corresponded to $0.09 \mathrm{mg}$ of $\mathrm{P}$ per mmol of salts per liter of water (Figure 5B2). The DH species was responsible for maintaining the highest $\mathrm{P}$ accumulation for all salt levels, even though it decreased by $37.52 \%$ from the increase of 0 to $40 \mathrm{mmol}_{\mathrm{c}} \mathrm{L}^{-1}$.

The differences observed in phosphorus accumulation from leaf tissues of mycorrhized papaya seedlings found herein can be explained by the variation of the characteristics of external mycelium for the different AMF genotypes regarding dimensions, branching patterns, as well as their ability to absorb nutrients at specific root distances (Smith \& Smith, 2012).

Inoculation with $\mathrm{DH}$ and $\mathrm{GC}$ provided the highest average $\mathrm{K}^{+}$concentrations and accumulations for salinity levels equal to or greater than $10 \mathrm{mmol}_{\mathrm{c}} \mathrm{L}^{-1}$, even though these values reduced at the highest salt concentrations in irrigation water (Figure $6 \mathrm{Al}$ and $\mathrm{Bl}$ ).

For $\mathrm{K}^{+}$concentration, a decreasing linear trend with increasing salinity was observed for plants inoculated with the species DH, GC and in WM, with reductions equivalent to $0.045,0.028$ and $0.073 \mathrm{~g} \mathrm{~kg}^{-1}$ per $\mathrm{mmol}_{\mathrm{c}}$ of salts for the three AMF species, respectively (Figure 6A2). In this sense, the lower tolerance of non-mycorrhized plants to salt stress was clear when compared to relative losses in $\mathrm{K}^{+}$concentration.

$\mathrm{K}^{+}$content decreased linearly with increasing salt concentrations for all mycorrhized treatments, with reductions of $0.233,0.231,0.133$ and $0.095 \mathrm{mg} \mathrm{plant}^{-1}$ for inoculation with DH, AS, WM and GC, respectively (Figure 6B2). Despite the greater reduction in $\mathrm{K}^{+}$accumulation in papaya seedlings inoculated with $\mathrm{DH}$, this treatment presented the highest $\mathrm{K}^{+}$content in all the salt concentrations, which may be related to the higher RWC in leaf tissues (Figure 6A). Elhindi et al. (2017) also found positive and significant relationships between potassium contents in mycorrhized plants and the degree of salinity tolerance.
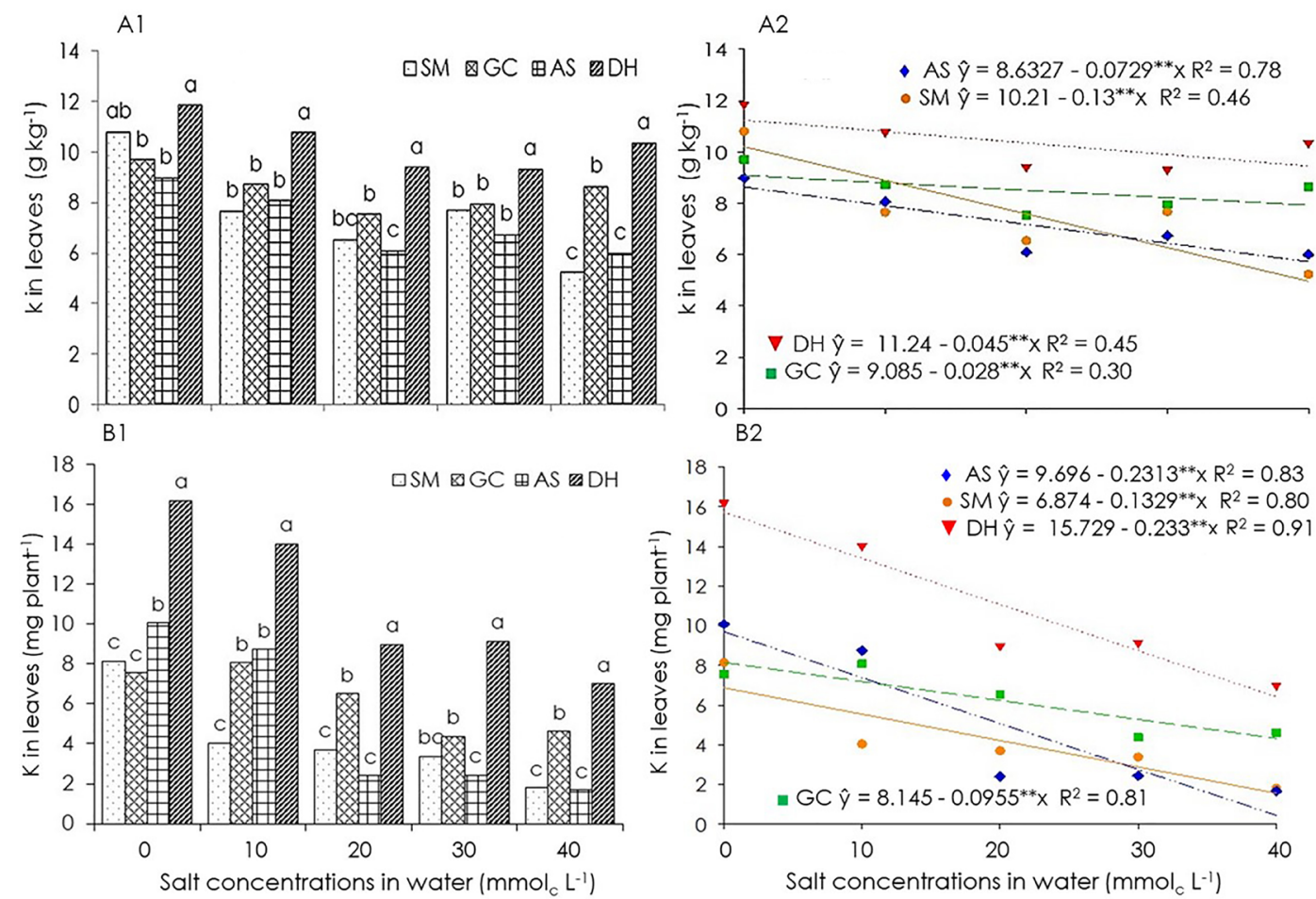

Figure 6. Concentration (A) and accumulation (B) of potassium (K) in leaves of papaya seedlings, 65 DAE, related to the mycorrhizae species within the salt concentrations (A1 \& B1) and the salt concentrations within each one of the mycorrhizae species (A2 \& B2). (WM) without mycorrhizae, (GC) Gigaspora candida, (AS) Acaulospora scrobiculata and (DH) Dentiscutata heterogama. Note: Means followed by the same letter do not differ by Tukey's test at a 5\% probability level (A1 \& B1).

Reductions in $\mathrm{K}^{+}$levels in the aerial part of melon plants exposed to increasing salinity levels were observed by Lúcio et al. (2013). The same authors also found that inoculation with AMF provided higher $\mathrm{K}^{+}$accumulations compared to non-inoculated plants.

Hashem et al. (2018) observed reduced $\mathrm{K}^{+}$ absorption by Cucumis sativus L. under saline conditions, however, improvements in the absorption of this element were identified in mycorrhized plants, with $46.71 \%$ higher content than in non-inoculated plants under conditions of high salinity. Furthermore, according to these authors, reduced absorption of this ion is caused by the 
antagonistic effect of sodium ( $\mathrm{Na}$ ) when competing for the same absorption sites since it becomes more difficult for carrier proteins to distinguish between $\mathrm{Na}$ and $\mathrm{K}^{+}$in saline environments when the proportion of these ions does not differ in the soil solution, resulting in decreased $\mathrm{K}^{+}$absorption and, consequently, lower accumulation in plant tissues (Blumwald, 2000).

Another cause of reduced $\mathrm{K}^{+}$absorption is the action of $\mathrm{NaCl}^{-}$in the depolarization of membranes which deactivates the specific $\mathrm{K}^{+}$channels, thus favoring greater incorporation of $\mathrm{Na}^{+}$in the protoplasm of plant cells (Silveira et al., 2010).

Salinity affected sodium concentrations and accumulation $\left(\mathrm{Na}^{+}\right)$differently depending on the mycorrhizae treatment, and statistical differences were observed between these treatments $(p<0.05)$ for salt concentrations greater than or equal to $10 \mathrm{mmol}_{\mathrm{c}} \mathrm{L}^{-1}$. At the salinity of $40 \mathrm{mmol}_{\mathrm{C}} \mathrm{L}^{-1}$, the $\mathrm{DH}$ species presented the lowest concentrations of $\mathrm{Na}^{+}\left(8.2 \mathrm{~g} \mathrm{~kg}^{-1}\right)$, above the highest accumulations in leaf tissue at 20 and $30 \mathrm{mmol}_{\mathrm{C}}$ $\mathrm{L}^{-1}$ saline levels (Figure $7 \mathrm{~B} 1$ and $\mathrm{B} 2$ ). These results are a consequence of the higher $\mathrm{Na}^{+}$absorption, due to its higher availability in the soil solution, considering that sodium chloride made up $70 \%$ of the total salts used to prepare the saline solution.

The increased salt concentration in irrigation water increased the $\mathrm{Na}^{+}$concentrations linearly, with mean increments of $0.170,0.316,0.324$ and $0.357 \mathrm{~g} \mathrm{~kg}^{-1}$ with each unit increase in water salinity for the DH, SM, GC and AS treatments, respectively (Figure 7A2).

The increase in salt concentrations up to $25.65 \mathrm{mmol}_{\mathrm{C}} \mathrm{L}^{-1}$ increased the $\mathrm{Na}^{+}$accumulation up to a maximum value of $7.43 \mathrm{mg}^{\text {plant }}{ }^{-1}$, consequently decreasing until $5.59 \mathrm{mg} \mathrm{plant}^{-1}$ at the highest salinity level $\left(40 \mathrm{mmol}_{\mathrm{C}} \mathrm{L}^{-1}\right)$ in papaya seedlings inoculated with $\mathrm{DH}$. For the other AMF species, increased salinity was correlated to a linear increase in $\mathrm{Na}^{+}$accumulation, where it became evident that until the $2.9 \mathrm{mg} \mathrm{plant}^{-1}$ accumulation obtained, as a function of $16.16 \mathrm{mmol}_{\mathrm{c}}$ $\mathrm{L}^{-1}$, the AS species presented the highest $\mathrm{Na}^{+}$averages when compared with $G C$ and until the accumulation of $3.96 \mathrm{mg}$ plant ${ }^{-1}$, obtained as a function of $29.85 \mathrm{mmol}_{\mathrm{C}} \mathrm{L}^{-1}$, when compared to the WM treatment (Figure 7B2).

Al

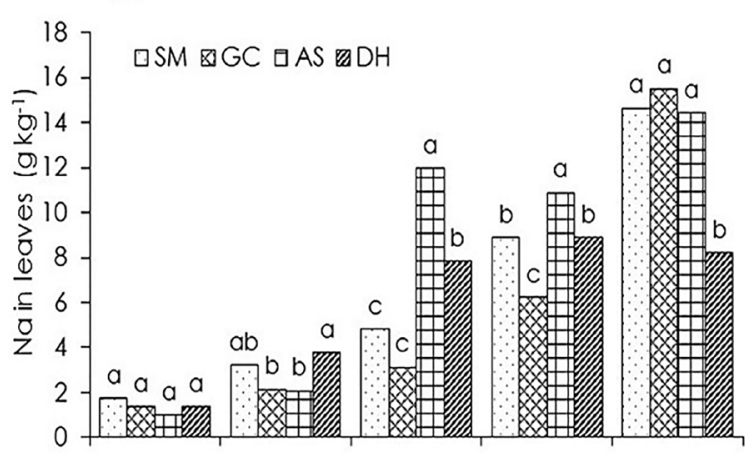

$A 2$

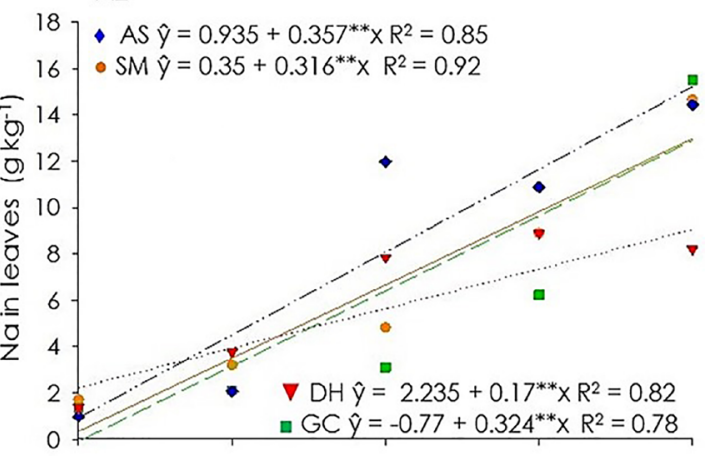

B1

B2
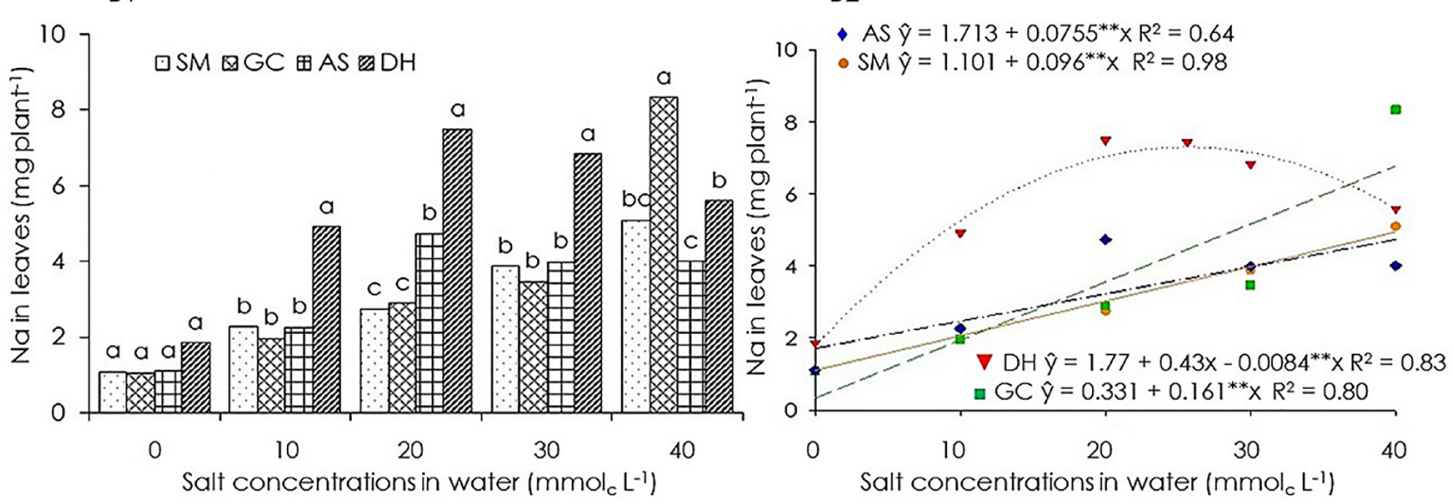

Figure 7. Concentration (A) and accumulation (B) of sodium ( $\mathrm{Na}$ ) in leaves of papaya seedlings, $65 \mathrm{DAE}$, related to the mycorrhizae species within the salt concentrations $(A 1 \& B 1)$ and the salt concentrations within each one of the mycorrhizae species (A2 \& B2). (WM) without mycorrhizae, (GC) Gigaspora candida, (AS) Acaulospora scrobiculata and (DH) Dentiscutata heterogama. Note: Means followed by the same letter do not differ by Tukey's test at a 5\% probability level (A1 \& B1).

Results from previous studies corroborate those observed in the present study regarding the decreased
$\mathrm{Na}^{+}$concentration in leaf tissue of cultivated plants submitted to increasing salt concentrations, due to 
mycorrhization with different AMF species. According to Elhindi et al. (2017), this reduction in $\mathrm{Na}^{+}$absorption per mycorrhization is a mechanism of partial relief to salt stress when associated with the reduced transfer of this ion from root to shoot.

Wu et al. (2013) studied citrus seedlings (Poncitrus trifoliata) with and without mycorrhizae for a period of 61 days, which were submitted to saline conditions 10 and $100 \mathrm{mM}$ Of $\mathrm{NaCl}$ ) for 45 days. They observed an increase in the $\mathrm{Na}^{+}$concentration in leaf tissue as a function of salinity independent from mycorrhizal inoculation, but the use of mycorrhizae decreased the concentration of this ion by up to $31 \%$ under saline stress condition $(100 \mathrm{mM}$ of $\mathrm{NaCl})$ when compared to no mycorrhizae. Amanifar et al. (2019) observed similar results when studying the effect of irrigation with increasing salt levels in Glycyrrhiza glabra plants with and without mycorrhizae. Similarly, Daei et al. (2009) evaluated the effect of different AMF species on salt stress attenuation in wheat plants and found that there was a significant reduction in $\mathrm{Na}^{+}$concentration in leaf tissue of plants with higher \%CM.

The relationship between $\mathrm{K}^{+}$and $\mathrm{Na}^{+}$levels was strongly affected by increased salinity, with the highest relationships observed in mycorrhized plants and varying according to the AMF species used. However, regardless of these microorganisms, the $\mathrm{K}^{+} / \mathrm{Na}^{+}$ratio decreased dramatically with increasing salinity (Figure 8). This behavior can be justified by the increase in $\mathrm{NaCl}^{-}$and the maintenance of $\mathrm{K}^{+}$doses, which were common for all treatments. However, even in these conditions, $\mathrm{K}^{+}$ absorption was favored by plants mycorrhized with the $\mathrm{DH}$ and $\mathrm{GC}$ species at the highest salt concentrations (30 and $40 \mathrm{mmol}_{\mathrm{C}} \mathrm{L}^{-1}$ ) (Figure 8).
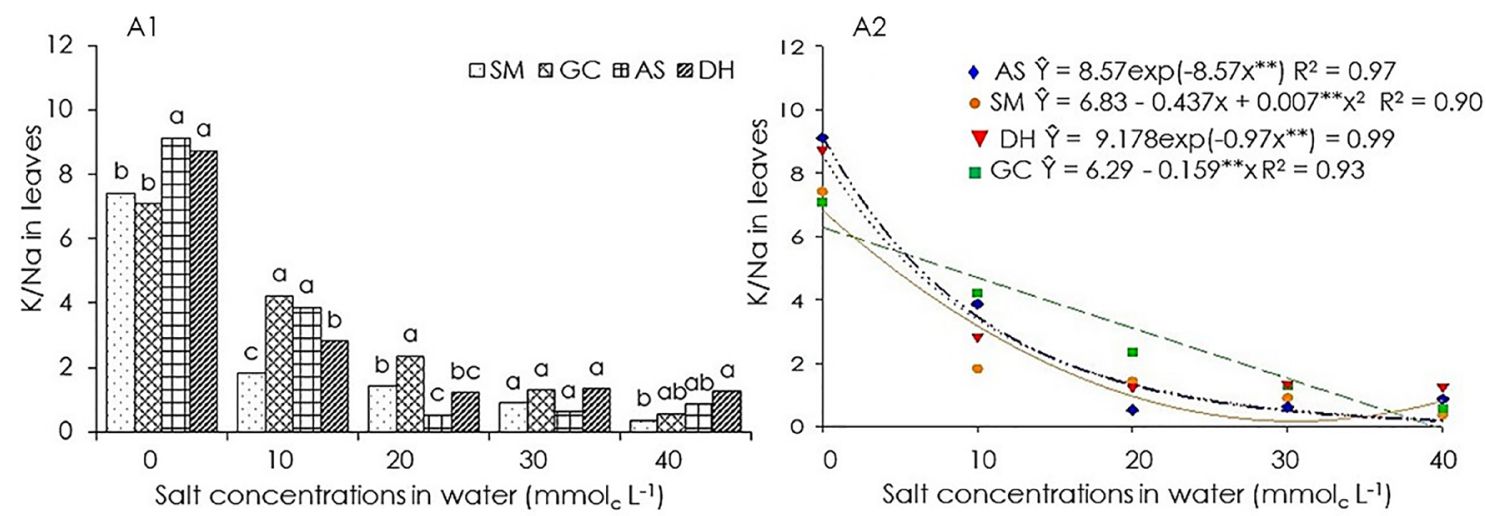

Figure 8. Relationship between concentrations of Potassium and Sodium $\left(\mathrm{K}^{+} / \mathrm{Na}^{+}\right)$in leaves of papaya seedlings, $65 \mathrm{DAE}$, related to the mycorrhizae species within the salt concentrations ( $\mathrm{A} 1$ \& $\mathrm{B} 1$ ) and the salt concentrations within each one of the mycorrhizae species (A2 \& B2). (WM) without mycorrhizae, (GC) Gigaspora candida, (AS) Acaulospora scrobiculata and (DH) Dentiscutata heterogama. Note: Means followed by the same letter do not differ by Tukey's test at a $5 \%$ probability level (A1 \& B1).

Daei et al. (2009) found different effects for AMF species in relieving salt stress in wheat plants and concluded that the plants with the highest percentage of mycorrhizae colonization were those with a lower $\mathrm{K}^{+} /$ $\mathrm{Na}^{+}$ratio and, consequently, a higher yield.

Similar results were observed by Elhindi et al. (2017) in their study related to the effect of salinity on the mineral nutrition of mycorrhized Ocimum basilicum L. plants. Despite a reduction in the $\mathrm{K}^{+} / \mathrm{Na}^{+}$ratio caused by the increased salinity these authors found that mycorrhizae inoculation provided the highest values for this variable regardless of the saline level, thus relieving the ionic imbalance induced by excess salts, which they stated to be a clear indication of the role of mycorrhizae in increasing $\mathrm{K}^{+}$absorption in salt stress conditions. According to Khallouf et al. (2017), mycorrhization also positively influenced saline stress due to improved $\mathrm{K}^{+}$ absorption and reduced $\mathrm{Na}^{+}$absorption by Solanum lycopersicum $\mathrm{L}$. plants and the $\mathrm{K}^{+} / \mathrm{Na}^{+}$ratio was positively correlated with growth of this plant species.

The correlation between nutritional variables and the study factors (mycorrhizae and salt concentrations of water) was evaluated by Pearson's linear correlation test (r) (Table 6), where different levels of significance were evidenced by the $t$ test at $5 \%$ probability.

A moderately positive and significant correlation $(p<0.01)$ was observed only between the $\mathrm{K}^{+}$concentration and the $\mathrm{K}^{+} / \mathrm{Na}^{+}$ratio $(r=0.47)$, a strong significant negative correlation $(p<0.01)$ was observed between $\mathrm{Na}^{+}$and $\mathrm{K}^{+} /$ $\mathrm{Na}^{+}(r=-0.76)$. For correlations of nutrient accumulation, $\mathrm{N}$ was positively correlated with $\mathrm{P}$ and $\mathrm{K}^{+}(\mathrm{r}=0.81$ and 0.88 , respectively) demonstrating a possible positive influence on absorption of these nutrients improved by nitrogen. 
Table 6. Pearson's simple correlation coefficient between the concentration and accumulation of total Nitrogen (N), Potassium (K), Phosphorus (P), Sodium (Na) and the relationship between $K$ and $\mathrm{Na}\left(\mathrm{K}^{+} / \mathrm{Na}^{+}\right)$in leaves of the Tainung $\mathrm{N}^{\circ} 1$ Formosa Papaya as a function of the mycorrhization and water irrigation at different salt levels.

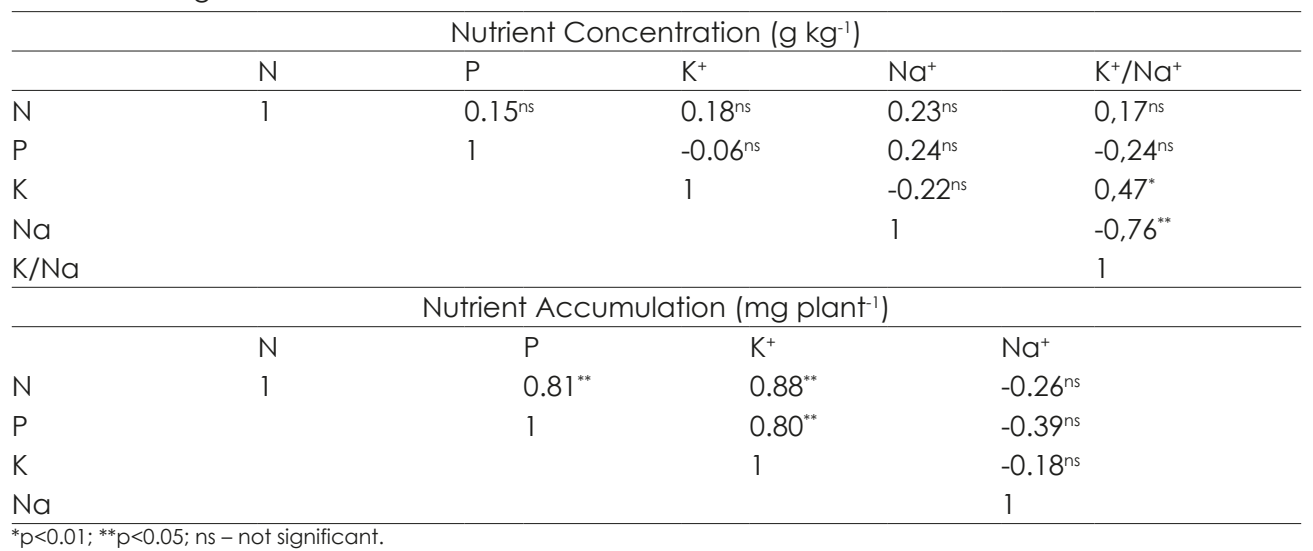

\section{Conclusions}

The species of arbuscular mycorrhizal fungi attenuated the deleterious effects of salinity on the nutritional, hydric and biochemical components of the papaya seedlings, however, the effects varied according to the fungi species and salinity level studied.

The species D. heterogama and G. providedndida presented the highest rates of leaf hydration and the lowest damage to biomembranes at all saline levels studied.

Mycorrhizae increased the absorption of $\mathrm{N}$ and $P$, mainly due to irrigation with water at salt concentration higher than $30 \mathrm{mmol}_{\mathrm{C}} \mathrm{L}^{-1}$.

A higher $\mathrm{K}^{+}$concentration, as well as a reduction in $\mathrm{Na}^{+}$, was evidenced in seedlings mycorrhized with $D$. heterogama.

\section{References}

Abd-Alla, M.H., Nafady, N.A., Bashandy, S.R., Hassan, A.A. 2019. Mitigation of effect of salt stress on the nodulation, nitrogen fixation and growth of chickpea (Cicer arietinum L.) by triple microbial inoculation. Rhizosphere 10:100-148.

Amanifar, S., Khodabandeloo, M., Mohsenifard, E., Askari, M.S., Ashrfi, M. 2019. Alleviation of salt stress and changes in glycyrrhizin accumulation by arbuscular mycorrhiza in liquorice (Glycyrrhiza glabra) grown under salinity stress. Environmental and Experimental Botany 160: 25-34.

Audry, P., Suassuna, J.A.A. 1995. Qualidade da água na irrigação do trópico semi-árido um estudo de caso. In: Seminário Franco-Brasileiro de Pequena Irrigação. Recife. Anais... CNPq/SUDENE, Recife, Brazil. p. 147-153.

Bezerra Neto, E., Barreto, L.P. 2011. Análises químicas e bioquímicas em plantas. UFRPE, Recife, Brazil. $261 \mathrm{p}$.

Blumwald, E. 2000. Sodium transport and salt tolerance in plants. Current Opinion in Cell Biology 12: 431-434.

Catsky, J. 1974. Water saturation déficit: relative water content. In: Slavik, B. (Ed.). Methods of studying plant water relations. Springer-Verlag, Berlin, Germany. p. 136154.

Chaudhary, M.T., Wainwright, S.J., Merrett, M.J. 1996. Comparative $\mathrm{NaCl}$ tolerance of Lucerne plants regenerated from salt-selected suspension cultures. Plant Science 144: 221-232.

Coelho, E.F., Filho, M.A.C., Cruz, J.L. 2008. Fundamentos e Manejo da Fertirrigação do Mamoeiro. EMBRAPA, Cruz das Almas, Brazil. 28 p.

Daei, G., Ardekani, M.R., Rejali, F., Teimuri, S., Miransari, M. 2009. Alleviation of salinity stress on wheat yield, yield components, and nutrient uptake using arbuscular mycorrhizal fungi under field conditions. Journal of Plant Physiology 166: 617-625.

Elhindi, K.M., El-Din, A.S., Elgorban, A.M. 2017. The impact of arbuscular mycorrhizal fungi in mitigating salt-induced adverse effects in sweet basil (Ocimum basilicum L.). Saudi Journal of Biological Sciences 24: 170-179.

Ferreira, D.F. 2014. SISVAR: a Guide for its Bootstrap procedures in multiple comparisons. Ciência e Agrotecnologia 38: 109-112.

Figueiredo Filho, D.B., Silva Júnior, J.A. 2009. Desvendando os Mistérios do Coeficiente de Correlação de Pearson (r). Revista Política Hoje 18: 115-146.

Garg, N., Singla, P. 2012. The role of Glomus mosseae on key physiological and biochemical parameters of pea plants grown in arsenic contaminated soil. Scientia Horticulturae 143: 92-101.

Gholamhoseini, M., Ghalavand, A., Dolatabadian, A., Jamshidi, E. Khodaei-Joghan, A. 2013. Effects of arbuscular mycorrhizal inoculation on growth, yield, nutrient uptake and irrigation water productivity of sunflowers grown under drought stress. Agricultural Water Management 117: 106-114.

Harris-Valle, C., Esqueda, M., Gutiérrez, A., Castellanos, A.E., Gardea, A.A., Berbara, R. 2018. Physiological response of Cucurbita pepo var. pepo mycorrhized by Sonoran desert native arbuscular fungi to drought and 
salinity stress. Brazilian Journal of Microbiology 49: 45-53.

Hashem, A., Abd-Allah, E.F., Alqarawi, A.A., Wirth, S., Egamberdieva, D. 2019. Comparing symbiotic performance and physiological responses of two soybean cultivars to arbuscular mycorrhizal fungi under salt stress. Saudi Journal of Biological Sciences 26: 38-48.

Hashem, A., Alqarawi, A.A., Radhakrishnan, R., Al-Arjani, A.F., Aldehaish, H.A., Egamberdieva, D., Abd-Allah, E.F. 2018. Arbuscular mycorrhizal fungi regulate the oxidative system, hormones and ionic equilibrium to trigger salt stress tolerance in Cucumis sativus L. Saudi Journal of Biological Sciences 25: 1102-1114.

Khallouf, M., Martínez-Andújar, C., Lachaâl, M., KarrayBouraoui, N., Pérez-Alfocea, F., Albacete, A. 2017. The interaction between foliar GA3 application and arbuscular mycorrhizal fungi inoculation improves growth in salinized tomato (Solanum lycopersicum L.) plants by modifying the hormonal balance. Journal of Plant Physiology 234: 134-144.

Lichthenthaler, H.K. 1987. Chlorophylls and carotenoids: pigments of photosynthetic biomembranes. Meth Enzimo 148: 350-383.

Lima, K.B., Martins, M.A., Freitas, M.S.M, Olivares, F.L. 2011. Fungos micorrizicos arbusculares, bactérias diazotróficas e adubação fosfatada em mudas de mamoeiro. Revista Brasileira de Fruticultura 33: 932-940.

Lúcio, W.S., Lacerda, C.F., Mendes Filho, P.F., Hernandez, F.F.F., Neves, A.L.R., Gomes Filho, E. 2013. Crescimento e respostas fisiológicas do meloeiro inoculado com fungos micorrízicos arbusculares sob estresse salino. Semina: Ciências Agrárias 34: 1587-1602.

Mendonça, V., Abreu, N.A.A., Gurgel, R.L., Ferreira, E.A., Orbes, M.Y., Tosta, M.S. 2006. Doses de nitrogênio e superfosfato simples no crescimento de mudas de mamoeiro 'Formosa'. Revista Ciência e Agrotecnologia 30: 1065-1070.

Miransari, J. 2017. Arbuscular Mycorrhizal Fingi and Soil Salinity. In: Johnson, N.C., Gehring, C., Jansa, J. (Org.). Mycorrhizal mediation of soil: Fertility, structure and carbon storage. Elsevier, Amsterdam, Netherlands. p. 263-277.

Navarro, A., Bañón, S., Morte, A., Sánchez-Blanco, M.J. 2011. Effects of nursery pre-conditioning through mycorrhizal inoculation and drought in Arbutus unedo L. plants. Mycorrhiza 21: 53-64.

Navarro, J.M., Tornero, O.P., Morte, A. 2014. Alleviation of salt stress in citrus seedlings inoculated with arbuscular mycorrhizal fungi depends on the rootstock salt tolerance. Journal of Plant Physiology 171: 76-85.

Sá, F.V.S., Brito, M.E.B., Melo, A.S., Neto, P.A., Fernandes, P.D., Ferreira, I.B. 2013. Produção de mudas de mamoeiro irrigadas com água salina. Revista Brasileira de Engrenharia Agrícola e Ambiental 17: 1047-1054.

Schimel, J.P., Bennett, J. 2004. Nitrogen mineralization: Challenges of a changing paradigm. Ecology 85: 591-
602.

Shanahan, J.F., Edwards, I.B., Quick, J.S.E., Fenwick, J.R. 1990. Membrane thermostability and heat tolerance of spring wheat. Crop Science 30: 247-251.

Silveira, J.A.G., Silva, S.L.F., Silva, E.N., Viégas, R.A. 2010. Mecanismos biomoleculares envolvidos com a resistência ao estresse salino. In: Gheyi, H.R., Dias, N.S., Lacerda, C.F. Manejo da salinidade na agricultura: estudos básicos e aplicados. Instituto Nacional de Ciência e Tecnologia em Salinidade, Campina Grande, Brazil. p. 161-180.

Smith, S.E., Smith, F.A. 2012. Fresh perspectives on the roles of arbuscular mycorrhizal fungi in plant nutrition and growth. Mycologia 104: 1-13.

Tedesco, M.J., Gianello, C., Bissani, C.A., Bohnen, H., Volkweiss, S.J. 1995. Análise de solo, plantas e outros materiais. 2.ed. Universidade Federal do Rio Grande do Sul, Porto Alegre, Brazil. 174 p. (Boletim Técnico de Solos, $5)$.

Trindade, A.V., Siqueira, J.O., Almeida, F.P. 2001. Dependência micorrízica de variedades comerciais de mamoeiro. Pesquisa Agropecuária Brasileira 36: 14851494.

Wu, Q.S., Zou, Y.N., He, X.H. 2010. Contributions of arbuscular mycorrhizal fungi to growth, photosynthesis, root morphology and ionic balance of citrus seedlings under salt stress. Acta Physiology Plant 32: 297-304.

Wu, Q.S., Zou, Y.N., He, X.H. 2013. Mycorrhizal symbiosis enhances tolerance to $\mathrm{NaCl}$ stress through selective absorption but not selective transport of $\mathrm{K}^{+}$over $\mathrm{Na}^{+}$in trifoliate orange. Scientia Horticulturae 160: 366-374.

Zhang, T., Hu, Y., Zhang, K., Tian, C., Guo, J. 2018. Arbuscular mycorrhizal fungi improve plant growth of Ricinus communis by altering photosynthetic properties and increasing pigments under drought and salt stress. Industrial Crops Products 117: 13-19.

Conflict of Interest Statement: The authors declare that the research was conducted in the absence of any commercial or financial relationships that could be construed as a potential conflict of interest.

All the contents of this journal, except where otherwise noted, is licensed under a Creative Commons Attribution License attribuition-type BY. 